\title{
The Development of Storytelling Learning Using BAHARI DONG Method at AL-YA'LU Superior Elementary School, Malang City, East Java
}

\author{
Endang Supadminingsih ${ }^{1 *}$, Nurhayati Nurhayati ${ }^{2}$ \\ ${ }^{1}$ Student of Indonesian Literature Study Program, Faculty of Cultural Sciences, \\ Hasanuddin University \\ ${ }^{2}$ Lecturer of Indonesian Literature Study Program, Faculty of Cultural Sciences, \\ Hasanuddin University \\ *Corresponding author. E-mail:endang.teacher2021@gmail.com
}

\begin{abstract}
Fairy tale was a literary work that entertained children and provided positive benefits for them. Almost every child was very happy to listen to the parents or teachers who were telling stories. However, very few students were ready to tell a story when they asked with the excuse of being embarrassed and inability. The research was conducted to find a solution to the difficulties of AL-YA'LU Superior Elementary School students in learning storytelling and to increase students' interest in participating in storytelling activities as a fun activity by using BAHARI DONG method. The research used a qualitative approach, in the form of Classroom Action Research. The research encompassed several procedures: planning, implementation, observation, and reflection. The research subjects were 20 students of the third grade of AL-YA'LU Superior Elementary School. The research data were analyzed qualitatively and quantitatively. The research was conducted in two cycles with the completion at second cycle, which provided five simpler fairytales, and students chose their fairytales to be told. The ability improvement of students' storytelling abilities from the initial conditions, first cycle, and second cycle was (a) Improving interest in storytelling, 25\%,75\%, and 90\%; (b) The fluency of storytelling with grade average 65, 78, 92 (scale value 10-100) (c) Intonation and articulation with grade average 70, 82, became 88; The achievement of fairytale content reached grade average 76, 86, and 94; (e) Expressions with grade averages 65, 74, and 90. The results of the research showed that The BAHARI DONG method is a good solution to improve the storytelling ability of AL-YA'LU Superior Elementary School students and increase students' interest in participating in storytelling activities as a fun activity.
\end{abstract}

Keywords: Storytelling, BAHARI DONG method

\section{INTRODUCTION}

Literary appreciation as one of the components of learning Indonesian has strategic to create to a generation that can raise the dignity of the Indonesian in the eyes of the world. There is a proverb that says "Language shows the nation. The good or bad character of a person can be seen from the speech or his language. Nurgiyantoro [1] wrote that literature talks about life and life, about various problems of human life, about life around humans, about life in general, all of which are expressed in a unique way and language, in literary language contains the elements and purposes of beauty. Literary language is more nuanced in beauty than practicality. These characteristics are also applied in children's literature. The most important potential strategy is the characteristics of literature that gives pleasure and understanding of life. Due to the literature always talking about life, it also provides a better understanding of life. The understanding comes from the exploration of various forms of life, secrets of life, discovery and disclosure of various kinds of human characters, and much other information that will enrich the knowledge and understanding of readers.

AL-YA'LU Superior Elementary School is committed to optimizing the literary appreciation to form the character of the students. Not only through intracurricular activities, but had literary appreciation also developed through extracurricular activities. In intracurricular activities, literary appreciation is part of learning Indonesian. Meanwhile, in extracurricular activities of AL-YA'LU Superior Elementary School, literary appreciation is developed in the field of 
Literature. In the field of literature, literary appreciation is developed in the form of writing and reading poetry, writing and reading pantun, writing and reading the poem, storytelling, and drama. In addition to literature, also developed the International Language, Electrical Engineering, Painting, Sound Art, and Dance Art.

In the implementation of extracurricular activities, there are problems. The interest of students to join in Literature Extracurricular is very low, no more than 5 children per period. The results of the data collection showed that the reason for the low interest of students in participating in the Literature extracurricular was they were afraid of storytelling, on the other hand, they did not find difficulties to create and reading poetry, pantun, poem and performing drama. On the other hand, students feel very burdened when they are asked to practice storytelling. Finding this phenomenon, the author feels very urgent to find a solution to storytelling activities that do not burden the students but become a fun activity. The author hopes by using the BAHARI DONG storytelling method, children will find it easy to learn storytelling.

\section{THE PROBLEMS AND RESEARCH OBJECTIVES}

The problems of this study are how the effect of the application of BAHARI DONG method on the storytelling ability of AL-YA'LU Superior Elementary School students, and how the BAHARI DONG method can improve the ability of students in learning storytelling. The research is conducted to find solutions to the difficulties of AL-YA'LU Superior Elementary School students in learning storytelling and to increase the students' interest in participating in Literature extracurricular development of AL-YA'LU Superior Elementary School.

\section{LITERATURE REVIEW}

\subsection{Fairy Tales in Children's World}

Puspitasari, Hidayatullah, and Rahman [2] states that fairy tale is a fun thing for children. Through fairy tales, they can imagine being anything, through fairy tales they can form children's characters. Moreover, a fairy tale can optimize the development of children's character to achieve thinking maturity. Khairani in Dewi [3] explains that stories and fairy tales have the same goal, namely conveying moral messages without giving the impression of being patronizing or obtruding children opinions. Children need to figure to do anything and do not force them, advising them without indoctrinating is very important. One of the activities to set an example for children is by telling stories or stories. Nuraini in Dewi [3] says that fairy tales provide several benefits for children, those are: "First of all is making the relationship between children and mother getting closer, secondly as an effective means to provide values without feeling directly advised, and thirdly educating children, either EQ (Emotional Quotient) or SQ (Spiritual Quotient). Dewi [3] writes that some benefits of the fairy tale for children are: (a) stimulating the thinking power, (b) functioning as an effective medium to embed various values and ethics to the children, even to foster empathy, (c) sharpening children's sensitivity toward sounds, (d) foster interest in reading, (e) foster empathy, (f) increase intelligence, $(\mathrm{g})$ foster a healthy sense of humour.

\subsection{Storytelling Skills}

Puspitasari, Hidayatullah, and Rahman [2] wrote that storytelling activities essentially could be done by everyone. It's just that when someone wants to do storytelling activities, of course, they have to make special preparations for the storytelling activity to go well. The preparations cover: (1) Selecting or writing a fairy tale. In addition, to choosing a fairy tale, of course, we can do other activities, namely writing a fairy tale. Today many fairy tales are written by themselves. A storyteller usually writes his fairy tale that is adapted to the children who will listen to the fairy tale. (2). Reading and understanding the fairy tale. After choosing or writing a fairy tale, the most important thing is reading and understanding the fairy tale.

\subsection{The Development of Storytelling Skills in the Educational Psychology Perspective}

Thalib [4] describes that educational psychology is a branch of psychology related to education, includes (a) a psychological review of humans in educational situations (general characteristics of human activity, characteristics of the human personality, individual characteristics, and differences in talent), and (b) psychological review of human in the educational process (learning problems, individual development, individual changes in the learning process, measurement and assessment of educational outcomes. In principle, the main psychological focus in psychology education is students, those are the psychological characteristics of the students in the educational process. In addition, there are many problems concerning the various potentials of students covering spiritual, social, emotional, academic, and physical potential, mental health problems, and evaluation of learning outcomes. As a good teacher, for the development of a potential learner's variety, the teacher's personality becomes an important factor, including warmth, sense of humour, caring, planning, hard work and self-discipline. Pieget in Thalib [4] in his observations concerning the children development is related to the age increasing. The implication toward education is certain concepts may not be understood by children before the children maturity arises. Wahab [5] writes that learning is an effort process so that what individuals do is to change attitudes and behaviour from not knowing to know, from having no attitude to be having the attitude, from unskilled to skilled at doing something. Learning is not just mapping the knowledge or information conveyed, but how to actively involve individuals in making or revising the learning result they receive into experiences and skills which are beneficial for themselves. Learning is a system that helps individuals learn and interact with learning resources and the environment. The definition of Learning is based on 
The Indonesian' Constitution No. 20 of 2003 about the National Education System, which legally provides an understanding of learning. Learning as a pedagogic concept can be interpreted technically as a systematic and systemic effort to create a potential learning environment to produce a learning process that leads to the development of individual potential as a student.

Mudjiran [6] said that Piaget argues that cognitive development goes through four stages. Hence, in the learning process, educators need to adjust the material taught toward the stages of students' cognitive development so it will be easy to be understood. Piaget believes that cognitive development needs to be considered by educators, but if it is ignored then children will have difficulties in learning so that the learning outcomes are low.

Several psychological aspects need to be considered in the learning process.

\section{A. Growth and Development of the Student.}

Educators need to understand the development of students because educators should be responsible for or understand the changes of students in the classroom. In addition, the educators also need to understand the development of children "whether the learning carried out is suitable for the children development or not."

\section{B. Intellectual Intelligence}

Intelligence is the personal ability to think about a problem faced, the ability to adapt, and also to make decisions. Sntrock (2011) in Mudjiono (2021) suggests the importance of understanding cognitive development in learning such as cognitive social theory, information processing, cognitive constructivist. In constructivist theory, it is explained that children construct their knowledge and understanding through cognitive processes.

\section{Memorizing}

In our daily life, the information processing in our memory is the main part of recognizing the environment including in learning activities. And without memory, we won't be able to remember everything that we have happened and what we have to do in our life. Educational psychologists emphasized the importance of memory problems, how students enrich and construct their memories so they will function optimally. In the learning process, memory problems, forgetfulness, and boredom are things that cannot be ignored and must be an urgent concern for educators. Educators need to reduce the obstacles that arise so forgetfulness can be minimized, and learning boredom can be avoided [6].

\section{Motivation}

Motivation is direct and sustainable energy that influences/affect people's behaviour. Motivation is a driving factor to do something. Sources of motivation are divided into two types, namely extrinsic and intrinsic motivation. Extrinsic motivation is influenced by the presence of incentives such as rewards or punishments. Students will study diligently when they will get a reward or avoid punishment (behaviourism theory). The intrinsic method is also called internal motivation, that someone does something because of an impulse from within him. The results of the study indicate that students study diligently and do assignments because it is their responsibility in learning. Intrinsic motivation will encourage students to study hard, be serious, and have high curiosity in exploring the subject matter. Psychologists and educators emphasize how important for students to develop motivation in the learning process. Motivation is a driving factor to do something. [6].

According to Djamarah (2011) in Masduki Yusron, Burlian Karoma, dan Yuliani (2019), there are three main topics in the scope of learning psychology, namely learning, learning processes, and learning situations. On the subject of learning, it consists of sub-subjects of discussion, namely (1) learning theories, (2) learning principles, (3) the nature of learning, (4) types of learning, (5) activities learning, (6) effective learning techniques, (7) characteristics of changes in learning outcomes, (8) manifestations of learning behavior, and (8) factors that influence learning.

The second subject is the learning process, which includes: (1) the stages of learning actions, (2) mental changes that occur during learning, (3) the influence of learning experiences on individual behavior in the speed of processing impressions and the limitations of individual capacities in learning, and (6) the problem of forgetting processes and the ability of individuals to process through transfer learning.

The third topic of discussion is the situation and environmental conditions: (1) physical, (2) non-physical, (3) social, and (4) non-social.

Wahab [5] writes that learning is an effort process so that what individuals do is to change attitudes and behavior from not knowing to know, from having no attitude to be having the attitude, from unskilled to skilled at doing something. Learning is not just mapping the knowledge or information conveyed, but how to actively involve individuals in making or revising the learning result they receive into experiences and skills which are beneficial for themselves. Learning is a system that helps individuals learn and interact with learning resources and the environment.

The definition of Learning based on The Indonesian' Constitution No. 20 of 2003 about the National Education System, which legally provides an understanding of learning. Learning as a pedagogic concept can be interpreted technically as a systematic and systemic effort to create a potential learning environment to produce a learning process that leads to the development of individual potential as student 


\section{RESEARCH METHODS}

The subject of this research was the 3rd-grade students of AL-YA'LU Superior Elementary School, which consisted of 20 children. This research was action research conducted in two cycles. The Research implementation of the first cycle was carried out in August-October 2020, and the second cycle was carried out during November-December 2020. In the pretreatment, students were prepared for storytelling by memorizing scripts and models. The research involved data collection before treatment, followed by data collection after applying the BAHARI DONG method at the first cycle. (Reading fairy tale sources, understanding the content of fairy tales, characterizing characters by modelling, accompaniment of storytelling preparation by the teacher). In the first, the source of the fairy tales was determined by the teacher. The results were evaluated since the results were unsatisfactory, continued in the second cycle, with the completion of increasing the number of fairy tales sources for students and they chose as their wishes. All data obtained were analysed qualitatively and quantitatively.

\section{RESULTS AND DISCUSSION}

\subsection{Students' Interest in Storytelling}

The results of this study indicated an increase in students' interest in storytelling as shown in table 1 below:

Table 1. Students' Interest in Storytelling

\begin{tabular}{|c|c|c|}
\hline $\begin{array}{c}\text { Pre } \\
\text { Treatment }\end{array}$ & First Cycle & Second Cycle \\
\hline $25 \%$ & $75 \%$ & $90 \%$ \\
5 children & 15 children & 18 children \\
\hline
\end{tabular}

In pre-treatment conditions, children interest in storytelling was very low, only $25 \%, 5$ out of 20 children. This little interest was due to some students being afraid if they had to memorize a long fairy tale script. They preferred to watch their friend's performance. With the modelling that was given earlier, students were bound by the nature of the model. While there were student limitations to imitate the model. Five children wanted to tell stories because they were worried if they got a bad score if they did not want to tell stories. This condition described the children psychology were burdened by a class activity.

Data from the treatment first cycle showed an increase in the students' interest up to $75 \%$. Interview results with students showed children motivated due to they had the chance to read fairy tale sourcebooks.
Children were very fond of reading. The teacher only instructed to read, the children were very enthusiastic. From 20 children, 15 children who were interested in storytelling and 5 children were not. 15 children enjoyed the stages of preparation for storytelling directed by the teacher, meanwhile, 5 children still did not want to tell stories for reasons of shame and difficulty.

\subsection{The Fluency of Storytelling}

The fluency of storytelling in pre-treatment, first and second cycle can be seen in Table 2 below.

Table 2. of Student Storytelling

\begin{tabular}{|c|c|c|}
\hline $\begin{array}{c}\text { Pre Treatment } \\
\text { (scale 0-100) }\end{array}$ & $\begin{array}{c}\text { First Cycle } \\
\text { (scale 0-100) }\end{array}$ & $\begin{array}{c}\text { Second Cycle } \\
\text { (scale 0-100) }\end{array}$ \\
\hline 65 & 78 & 92 \\
\hline
\end{tabular}

Fluency The fluency of storytelling was assessed on the third day of characterization assistance. In pretreatment students were still very substandard, with an average fluency score of 65 until the third day of mentoring. The results of the first cycle showed fluency of 78 and in the second cycle reached an average fluency of 92. This condition could be explained that using the pre-treatment method children had difficulties in memorizing due to the students had to force themselves to memorize. The thing often occurred was if the student forgot just one word, it would be difficult to continue storytelling, which caused discouragement. Using the first cycle of BAHARI DONG method students had the freedom to express the information and messages they conveyed without being bound by memorization and modelling. However, the improvement was not satisfactory. This condition could be explained due to the students reading fairy tale sourcebooks according to the teacher direction, not based on their own choice. This was a reason to conduct the implementation scenario of the second cycle. In the second cycle, children were free to choose the source of the fairy tale based on their wishes and easy to tell.

The results of the second cycle were shown with the fluency achievement average reaching 92.

\subsection{Intonation and Articulation}

Intonation and Articulation were very important in storytelling. Both of them related to the clarity of the message and information conveyed by the storyteller to the listener/audience. The average achievement of students' intonation and articulation scores in this study was shown in table 3 below.

Table 3. Students' Achievement Average of Intonation and Articulation 


\begin{tabular}{|c|c|c|}
\hline $\begin{array}{c}\text { Pre Treatment } \\
\text { (scale 0-100) }\end{array}$ & $\begin{array}{c}\text { First Cycle } \\
\text { (scale 0-100) }\end{array}$ & $\begin{array}{c}\text { Second Cycle } \\
\text { (scale 0-100) }\end{array}$ \\
\hline 70 & 82 & 88 \\
\hline
\end{tabular}

\subsection{Expression}

In storytelling activities, the expression could add clarity to the message and information conveyed by the storyteller. The expression also conveys the audience emotions into the atmosphere of the fairy tale content conveyed by the storyteller. The achievement of expression formation in this study was shown in Table 4.

Table 4. Expression Value Achievement

\begin{tabular}{|c|c|c|}
\hline $\begin{array}{c}\text { Pre Treatment } \\
\text { (scale 0-100) }\end{array}$ & $\begin{array}{c}\text { First Cycle } \\
\text { (scale 0-100) }\end{array}$ & $\begin{array}{c}\text { Second Cycle } \\
\text { (scale 0-100) }\end{array}$ \\
\hline 65 & 74 & 90 \\
\hline
\end{tabular}

From the above achievements, it could be explained that students' doubts and worries toward mastery of fairy tale material greatly affect the expressions. In the preaction and first cycle, there was still a lack of appearance. By giving flexibility to the students to choose the fairy tale to be performed, students could express themselves freely. From all of the storytelling skills indicators, it could be seen that the BAHARI DONG method was able to improve the storytelling abilities of AL-YA'LU Superior Elementary School students.

\section{Chart 1. Integrated Result}

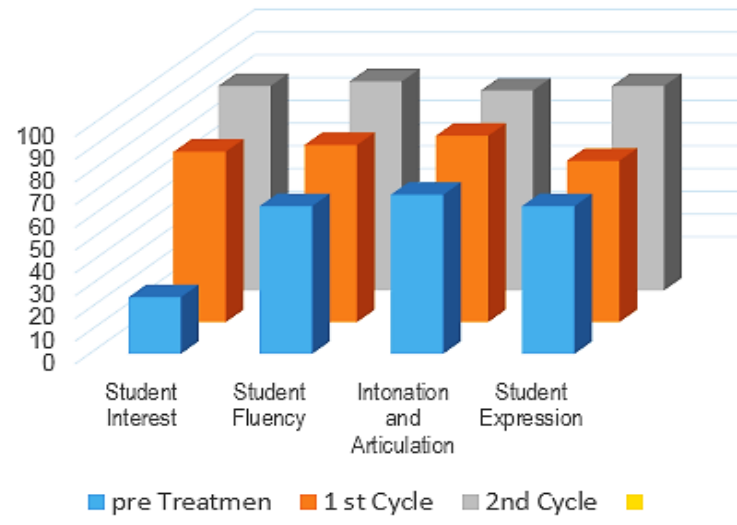

The overall data is shown in chart 1 above. The students' interest in storytelling showed the greatest increase compared to the other three indicators, fluency, intonation and articulation, as well as expression in storytelling. Although not as high as the interest in the increase, the three indicators show an increase that exceeds the passing grade. The increase in student interest is followed by an increase in fluency, intonation and articulation, as well as expression in storytelling. It can be explained that interest as an internal motivation provides a strong impetus for students to compose the imagination of story flow to further improve fluency, improve intonation and articulation, as well as their expression in storytelling.

\section{CONCLUSION}

From the results of this study it can be concluded that: (1) The Implementation of the BAHARI DONG method was able to improve the storytelling ability of AL-YA'LU Superior Elementary School students. (2) The improvement of students' storytelling skills using the BAHARI DONG method conducted in two cycles marked by the following indicators:

a. The students' interest in storytelling increased very significantly, $25 \%$ to $90 \%$.

b. The fluency of storytelling score increased from 65 to 92.

c. Intonation and articulation increased from 70 to 88 .

d. Students' expressions during storytelling increased from 65 to 90.

\section{ACKNOWLEDGMENTS}

Author's sincere gratitude to Father and Mother for becoming an inspiration in every work. The authors also express their gratitude to the Dean of the Faculty of Cultural Sciences, Hasanuddin University, Head of the Indonesian Literature Study Program at the Doctoral Education Level (S3), and other lecturers at the Faculty of Humanities, Hasanuddin University for his knowledge and guidance. May we all always be in the protection of Allah in carrying out the mandate of this education. Aamiin Ya Robbal Aalamiin.

\section{REFERENCES}

[1] Nurgiyantoro, B. (2018) Sastra Anak Pengantar Pemahaman Dunia Anak. Gadjah Mada University Press

[2] Puspitasari, N.A., Hidayatullah, S., \& Jupri, .R.A (2018). Keterampilan Mendongeng. Pustaka Ranggon

[3] Kesumadewi, V. (2021). Keajaiban Dongeng Teori dan Praktek Mendongeng. Cipta Media Nusantara.

[4] Thalib, S.B (2010). Psikologi Pendidikan Berbasis Analisis Empiris Aplikatif. Prenada Media Group

[5] Wahab, G., Rosnawati. (2021) Teori-Teori Belajar dan Pembelajaran. Penerbit Adab

[6] Mudjiran.(2021). Psikologi Pendidikan: Penerapan Prinsip-Prinsip Psikologi dalam Pembelajaran. Kencana 